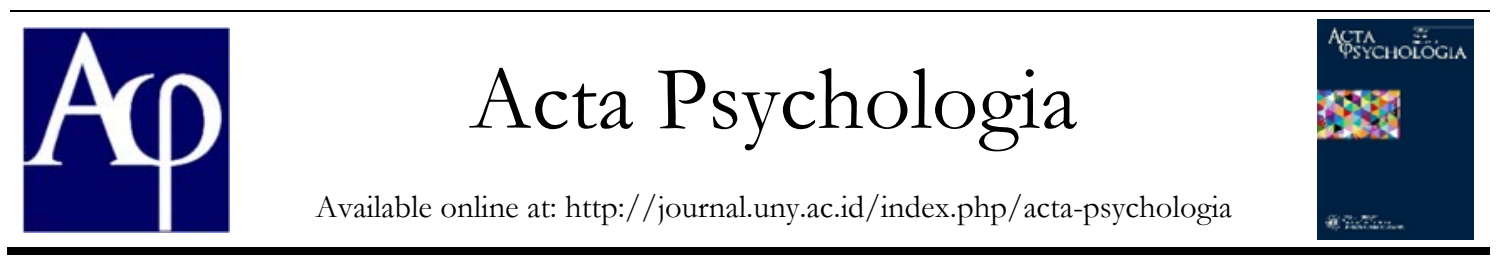

\title{
Pengembangan Skala Pemaafan Diri (Self-forgiveness)
}

\author{
Dyah Ayu Larasati', Tria Widyastuti ${ }^{2}$ \\ Jurusan Psikologi, Universitas Negeri Yogyakarta; Jl. Colombo No. 1 Sleman Yogyakarta, 55281 \\ dyahayu.2017@student.uny.ac.id \\ triawidya06@uny.ac.id
}

\begin{abstract}
Abstrak
Individu memiliki cara yang berbeda dalam merespon kesalahan yang diperbuat. Ada yang cepat memaakan kesalahan diri sendiri, namun ada yang butuh waktu lama atau bahkan membenci diri sendiri karena kesalahan yang diperbuat. Konsep penting terkait hal tersebut yaitu pemaafan diri yang ternyata berimbas positif pada kesejahteraan psikologis dan kesehatan mental. Pengukuran pemaafan diri kemudian menjadi penting untuk mendukung semakin banyaknya penelitian pemaafan diri. Namun begitu, meski di luar sudah dikembangkan beberapa skala pemaafan diri, di Indonesia belum banyak ditemukan penelitian yang khusus mengembangkan atau mengadaptasi skala ini. Dalam tulisan ini, peneliti bertujuan mengembangkan skala pemaafan diri yang diharapkan menjadi alat ukur yang valid dan reliabel. Peneliti melakukan tujuh tahapan pengembangan skala yaitu: (1) penentuan konstrak ukur, (2) penyusunan indikator-aitem, (3) pengujian validitas isi, (4) uji coba, (5) uji lapangan, (6) seleksi aitem, dan (7) penyusunan skala final. Hasil akhir penelitian ini dihasilkan 13 aitem skala pemaafan diri yang memiliki daya beda berkisar .337 hingga .676 dan reliabilitas Cronbach's alpha ditemukan .798 (dimensi mengakui tanggung jawab) dan .779 (dimensi memperbarui diri). Skala pemaafan diri juga memiliki struktur internal yang cukup baik. Hasil analisis faktor dengan principal component analysis pada 13 aitem didapat nilai $\mathrm{KMO}=.833$, Barlett's Test of sphrecity $\chi^{2}(78)=447.594, \mathrm{p}<.01$. Dua dimensi pemaafan diri mampu menjelaskan sebesar $49.891 \%$ varian.
\end{abstract}

Kata Kunci: pemaafan diri, self-forgiveness, pengembangan skala, validitas, reliabilitas

\begin{abstract}
Individuals have different ways of responding to their mistakes. Some people are quick to forgive their mistakes, but some need a longer time or even hate themselves because of the mistakes they made. Self-forgiveness becomes an important topic related to this which has a positive impact on psychological well-being and mental health. The measurement of self-forgiveness then becomes important to support the growing number of selfforgiveness research. However, even though some self-forgiveness scales have been developed outside of Indonesia, there are a few studies on developing a self-forgiveness scale. Researchers conducted seven stages of scale development consisting: (1) conceptualization construct, (2) writing indicators and items, (3) content validity testing, (4) trials, (5) field testing, (6) item selection, and (7) constructing the final scale. The 13 items selfforgiveness scale had discriminating power ranging from .337 to .676 and the reliability of Cronbach's alpha was found .798 (the dimension acknowledging responsibility) and .779 (the self-renewing dimension). The selfforgiveness scale has a fairly good internal structure. The results of factor analysis with principal component analysis on 13 items obtained the value of $\mathrm{KMO}=.833$, Barlett's Test of Sphericity c2 (78) $=447,594, \mathrm{p}<.01$. Two dimensions of self-forgiveness can explain $49.891 \%$ of the variance.
\end{abstract}

Keywords: self-forgiveness, scale construction, validity, reliability

\section{Pendahuluan}

Tidak ada manusia sempurna, yang terlepas dari kesalahan. Dalam merespon kesalahan, ada individu yang cepat memakluminya, namun ada yang sampai di kondisi hingga individu mengutuk dan membenci dirinya sendiri atas kesalahan yang diperbuat. Kondisi ini bisa terjadi jika ada banyak 
tekanan yang dirasakan individu akibat kesalahan yang diperbuat. Perasaan mengutuk diri sendiri mungkin dilakukan individu dalam upaya mengatasi pengalaman terkait penyesalan atas kesalahan yang telah dilakukan. Penyesalahan akan kesalahan kadang bisa membuat individu sampai mengisolasi diri dari orang lain atau bahkan membahayakan diri sendiri. Konsep pemaafan diri mulai menjadi perhatian ketika peneliti menemukan bahwa terkadang individu merasa bahwa orang yang paling sulit diampuni adalah diri sendiri (Woodyatt, Worthington, Wenzel, \& Griffin, 2017).

Definisi awal pemaafan diri diajukan Enright (1996) yang mendefinisikan pemaafan diri sebagai kesediaan meninggalkan kebencian diri akan tujuan yang diakui salah, sambil memupuk belas kasih, kemurahan hati, dan cinta terhadap diri sendiri. Definisi lain dari Hall dan Fincham (2005; Worthington, 2013) bahwa pemaafan diri merupakan pengalaman menurunnya pikiran negatif dan peningkatan secara positif pada perasaan dan perilaku terhadap diri sendiri. Kemudian Cornish dan Wade (2015) mengartikan pemaafan diri sebagai proses ketika individu menerima tanggung jawab karena menyakiti orang lain, menyesal, merestorasi melalui perilaku yang dapat memperbaiki, serta berkomitmen kembali pada nilai- nilai. Sikap memaafkan diri meningkatkan rasa memiliki dan harga diri kita ketika merasa kesalahan atau kegagalan mengancam kebutuhan psikologis (Woodyatt et al., 2017). Berdasarkan pengertian beberapa ahli, peneliti menyimpulkan bahwa pemaafan diri adalah kebersediaan diri untuk menerima diri dengan meninggalkan kebencian pada diri sendiri, meningkatkan perasaaan belas kasih pada diri, dengan melepaskan berbagai emosi yang dapat menekan diri sehingga dapat meningkatkan pikiran dan perasaan positif pada diri sendiri.

Pada awalnya, beberapa peneliti bingung membedakan konsep pemaafan diri dengan pemaafan pada orang lain karena keduanya sering dibahas dalam topik sama. Keduanya memiliki perbedaan pada tiga hal yaitu: (1) Pemaafan diri merupakan pengampunan dari pelaku yang lebih bersifat intrapersonal meski pemaafan terhadap diri dibersamai perasaan diampuni oleh orang lain atau Tuhan, (2) Memaafkan orang lain terkait dengan tradisi agama atau keyakinan individu, dan (3) Memaafkan diri membawa keprihatinan tentang kesenangan diri, dan kebanggaan, serta cara mengatasi tekanan emosional karena ketidaksesuaian antara nilai seseorang dan perilaku (Toussaint, Barry, Angus, Bornfriend, \& Markman, 2017).

Konsep pemaafan diri mulai muncul pada awal hingga pertengahan 1990-an. Penelitian awal tentang pemaafan diri oleh Enright (1996) menggambarkan triad atau tiga aspek pengampunan meliputi: (1) intervensi untuk membantu orang memaafkan orang lain, (2) menerima pengampunan dari orang lain, dan (3) memaafkan diri sendiri. Tahun 1997, Yayasan John Templeton mendanai Request for Proposals (RFP) tentang pemaafan yang melibatkan ilmuwan dalam penelitian tentang aspek pemaafan. Pada perkembangan selanjutnya, Woodyatt et al., (2017) mengemukakan bahwa sebagian besar studi memaafkan diri cenderung bersifat cross-sectional. Namun, pemaafan diri adalah proses perubahan yang sulit 
ditangkap secara empiris karena terungkap dalam kerangka waktu yang berbeda dan dengan cara yang berbeda untuk individu yang berbeda.

Disampaikan Hall dan Fincham (2005) bahwa menyadari kesalahan dan menerima tanggung jawab memulai perasaan bersalah dan penyesalan yang kemudian mengarahkan pada pemaafan diri. Pemaafan diri tumbuh jika seseorang mulai jujur dalam menghadapi dan bergulat dengan kesalahan diri sendiri (Fisher \& Exline, 2006). Bagaimana pengalaman melakukan kesalahan berhasil melampaui pengalaman pengutukan diri, sehingga dapat melepaskan diri dari penghukuman diri dan mencapai pengampunan diri menjadi tantangan dari penelitian pemaafan diri (Cornish \& Wade, 2015). Penelitian terkini banyak menemukan pengaruh positif dari pemaafan diri yaitu bahwa pemaafan diri berhubungan positif dengan peningkatan kesejahteraan psikologis (Fincham \& May, 2019), kesehatan mental (Tenklova \& Slezackova, 2016), dan kepuasan hidup (Yao, Chen, Yu, \& Sang, 2017).

\section{Dimensi Pemaafan Diri}

Dengan adanya banyak penemuan yang mendukung bahwa pemaafan diri memberi banyak manfaat positif bagi individu, alat ukur pemaafan diri perlu dikembangkan. Beberapa ahli mengemukakan dimensi pemaafan diri. Cornish dan Wade (2015) mengungkapkan empat komponen proses pemaafan diri, yaitu: (1) Responsibility (tanggung jawab) yang diartikan bahwa untuk mencapai pemaafan diri, seseorang yang turut bertanggung jawab atas tindakannya, (2) Remorse (Penyesalan), yaitu sebagai respon dari tanggung jawab, individu kerap mengalami berbagai macam emosi seperti rasa malu yang harus dikurangi, (3) Restoration (Pemulihan), yaitu langkah yang berorientasi pada tindakan yang mengikuti tanggung jawab dan penyesalan, dan (4) Renewal (Pembaruan), yaitu ketika akhirnya seseorang memperoleh keadaan emosional dari pemaafan diri yang melibatkan belas kasih, penerimaan, serta penghargaan pada diri sendiri.

Adapun Woodyatt et al., (2017) mengemukakan terdapat dua dimensi utama pada pemaafan diri. Pertama, mengakui tanggung jawab, yaitu pemaafan diri melibatkan kemampuan untuk bekerja melalui apa yang telah terjadi, mengakui tanggung jawab tanpa melepaskan diri dari kesalahan atau menyalahkan diri sendiri untuk hal-hal di luar kendali seseorang, berusaha untuk memperbaiki hubungan jika memungkinkan, dan melepaskan dari diri sendiri. Kedua, memperbarui harga diri, yaitu pemaafan diri melibatkan kemampuan untuk mengakui kegagalan yang dirasakan yang telah dialami dan, dengan melakukan itu, dapat pula memulihkan harga diri.

\section{Instrumen Pemaafan Diri yang sudah ada}

Beberapa peneliti telah mengembangkan alat ukur pemaafan diri, di antaranya yaitu: (1) Forgiveness of Self Subscale (FOSS) dikembangkan oleh Mauger, Perry, 
Freeman, Grove, dan al., (1992), (2) Multidimensional Forgiveness Scale (MFS) oleh Tangney, Boone, Fee, dan Reinsmith (Woodyatt et al., 2017), dan (3) Heartland Forgiveness Scale (HFS) oleh (Thompson \& Snyder, 2005).

FOSS dari Mauger (Woodyatt et al., 2017) terdiri dari 15 pernyataan benar atau salah, seperti "Saya merasa sulit untuk memaafkan diri sendiri untuk beberapa hal yang telah saya lakukan," "Saya sering merasa gagal untuk menjalani kehidupan yang benar.” Skor yang lebih tinggi mencerminkan tingkat pengampunan diri yang lebih rendah. FOSS memiliki beberapa kekurangan terkait validitas konstruk yaitu bahwa: (1) Beberapa item FOSS ditemukan mengukur sesuatu selain pengampunan diri, serta (2) beberapa pernyataan kurang relevan dengan responden yang tidak beragama.

MFS dari Tangney, Boone, Fee, dan Reinsmith (Woodyatt et al., 2017) menyajikan delapan skenario yang berbeda. Misalnya, responden diminta membayangkan bahwa saudaranya memberi tahu rahasia yang tidak boleh diberitahukan kepada orang lain, tetapi rahasia tersebut kita beritahukan kepada orang lain. Responden kemudian ditanya, seberapa besar kemungkinan mereka untuk memaafkan diri dalam setiap skenario. Peneliti mengumpulkan skor di seluruh skenario untuk memberikan indikasi tingkat pengampunan diri. Heartland Forgiveness Scale (HFS) dari Thompson dan Snyder (2005) terdiri dari 18 aitem dengan tuju pilihan rating kategori dari 1 (almost always false of me) hingga 7 (almost always true of me). HFS ini terdiri dari tiga subskala: (1) forgiveness of self (aitem 1-6), (2) forgiveness of others (aitem 7-12), dan (3) forgiveness of situations (aitem 13-18).

Di Indonesia, penelitian tentang pemaafan diri sudah cukup banyak diteliti antara lain penelitian Dinamika self-forgiveness pada pelaku perselingkuhan (Wijayanti, 2016) dan peningkatan kualitas hidup dengan pemaafan (Nashori, 2011). Skala pemaafan diri ditemukan di beberapa penelitian korelasi yang dilakukan Manafe (2014) serta Ferawati dan Rahmandani (2020). Dalam penelitian Manafe (2014) mengembangkan 14 aitem skala pemaafan diri yang terdiri dari aspek perasaan, pikiran, perilaku, dan sosial. Koefisien reliabilitas dalam penelitiannya ditemukan .780. Adapun Ferawati dan Rahmandani (2020) dengan mengembangkan 20 aitem skala pemaafan diri yang disusun berdasar aspek pemaafan diri dari Cornish dan Wade. Adapun koefisien reliabilitas skala ini ditemukan .878. Namun penelitian yang khusus mengembangkan skala pemaafan diri masih sulit ditemukan di Indonesia. Salah satu yang ditemukan ada dari Agung (2015) mengembangkan dan memvalidasi Pengukuran Pemaafan TRIM-18 yang berfokus pada hubungan interpersonal dengan pendekatan tiga motif (avoidance, revenge, dan benevolence). Namun begitu skala ini tidak memenuhi fit uji kecocokan model.

Berdasarkan pemaparan sebelumnya, peneliti menyimpulkan bahwa pemaafan diri penting untuk diteliti. Hal ini karena pemaafan diri memiliki imbas positif bagi individu terkait kesejahteraan psikologis dan kesehatan mental. Namun begitu, untuk pelaksanaan penelitian terkait pemaafan diri, alat ukur pemaafan diri di Indonesia masih belum banyak 
dikembangkan. Hal ini terbukti belum banyak artikel penelitian yang khusus membahas pengembangan ataupun adaptasi skala pemaafan diri. Terkait hal tersebut, dalam penelitian ini, peneliti bertujuan untuk mengembangkan skala pemaafan diri yang memiliki kualitas psikometris yang baik.

Tabel 1.

Blue-print skala pemaafan diri

\begin{tabular}{cllcc}
\hline No & \multicolumn{1}{c}{ Dimensi } & \multicolumn{1}{c}{ Indikator } & Aitem & Jumlah \\
\hline 1. & $\begin{array}{l}\text { Mengakui } \\
\text { tanggung jawab }\end{array}$ & $\begin{array}{l}\text { Bertanggung jawab tanpa } \\
\text { melepaskan kesalahan yang telah } \\
\text { diperbuat } \\
\text { Berusaha memperbaiki kesalahan } \\
\text { yang dibuat } \\
\text { Mengakui kegagalan yang dialami }\end{array}$ & $1,2,3$, & 3 \\
& & 8,9,10,11 & 4 \\
\hline 2. & $\begin{array}{l}\text { Memperbaharui } \\
\text { harga diri }\end{array}$ & $\begin{array}{l}\text { Berhenti menyalahkan diri sendiri } \\
\text { Berusaha memulihkan harga diri }\end{array}$ & $12,13,14,15$ & 4 \\
\end{tabular}

Metode Penelitian

Pengembangan skala pemaafan diri (selfforgiveness) dilakukan berdasar penggabungan langkah penyusunan skala dari Azwar (2016), Cohen dan Swerdlik (2010) serta Furr (2011). Ada tujuh tahapan yang dilakukan yaitu: (1) penentuan konstrak ukur, (2) penyusunan indikatoraitem, (3) pengujian validitas isi, (4) uji coba, (5) uji lapangan, (6) seleksi aitem, dan (7) penyusunan skala final.

Tahap 1, peneliti menentukan konstrak pemaafan diri. Penentuan konstrak dilakukan melalui studi literature yang dilakukan peneliti. Hasil studi literature, peneliti menggunakan dua dimensi pemaafan diri dari Woodyatt, Worthington, Wenzel, \& Griffin (2017). Dua dimensi tersebut yaitu yaitu mengakui tanggung jawab dan memperbarui harga diri. Dimensi mengakui tanggung jawab melibatkan kemampuan untuk bekerja melalui apa yang telah terjadi, mengakui tanggung jawab tanpa melepaskan diri dari kesalahan atau menyalahkan diri sendiri untuk hal-hal di luar kendali seseorang, berusaha untuk memperbaiki dan memperbaiki hubungan. Adapun dimensi membarui harga diri melibatkan kemampuan mengakui kegagalan, yang dengan melakukan itu, dapat memulihkan harga diri.

Tahap 2, dilakukan penyusunan aitem awal yang disusun dari penjabaran dua dimensi pemaafan diri menjadi 5 indikator (Error! Reference source not found.). Aitem pemaafan diri di tahap awal penyusunan terdiri dari 19 aitem. Adapun format respon skala terdiri dari empat pilihan yang diberi skor 1 (Sangat Tidak Sesuai), 2 (Tidak Sesuai), 3 (Sesuai), dan 4 (Sangat Sesuai).

Tahap 3, dilakukan uji validitas pada 19 aitem yang disusun. Tahapan ini penting sebab validitas merupakan kunci utama dalam menyusun instrumen yang menggambarkan bahwa aitem yang 
disusun mampu mengukur tujuan dari pengukuran yang ditetapkan (Gregory, 2015). Uji validitas yang dilakukan yaitu validitas isi (content validity). Aitem dinilai oleh rater terkait kesesuaiannya dengan perilaku yang diukur berdasar indikatornya (Allen \& Yen, 1979; Azwar, 2015). Kesesuaian indikator dan aitem dinilai berdasar lima kategori rating dari sangat tidak relevan (1) hingga sangat relevan (5). Hasil penilaian rater kemudian dihitung untuk mendapat indeks Aiken's V. Aitem dengan validitas isi yang baik merupakan aitem dengan indeks Aiken's $\mathrm{V}$ melebihi kriteria minimal yang ditetapkan Aiken (1985) berdasar jumah rater terlibat dan kategori rating yang digunakan.

\section{Tabel 2.}

Aitem awal skala pemaafan diri

\begin{tabular}{|c|c|}
\hline No & Isi Aitem \\
\hline 1 & $\begin{array}{l}\text { Saya melakukan tugas dan kewajiban saya sebagaimana mestinya meskipun saya telah melakukan } \\
\text { kesalahan }\end{array}$ \\
\hline $2^{* *}$ & $\begin{array}{l}\text { Saya mampu melakukan rutinitas harian saya meskipun saya telah melalui berbagai hal yang saya rasa } \\
\text { melelahkan dan kerap membuat saya menyesal dan bersalah }\end{array}$ \\
\hline 3 & Saya bertanggung jawab atas kesalahan yang saya lakukan \\
\hline 4 & Apabila melakukan kesalahan saya berusaha mencari jalan keluarnya \\
\hline 5 & Saya mampu untuk memperbaiki kesalahan yang saya buat \\
\hline 6 & Ketika saya melakukan kesalahan saya berusaha untuk memperbaikinya \\
\hline 7 & Meskipun saya merasa memperbaiki kesalahan merupakan hal yang sulit saya tidak menyerah begitu saja \\
\hline $8^{*}$ & Saya menganggap tiap kegagalan yang saya alami merupakan bagian dari diri saya \\
\hline $9 * * *$ & Saya meyakini bahwa gagal dalam suatu hal merupakan hal yang wajar \\
\hline $10^{* * *}$ & Tiap kegagalan yang saya alami akan saya jadikan pelajaran dan pengalaman berharga \\
\hline 11 & Kegagalan yang saya alami tidak akan mengganggu saya untuk tetap berproses \\
\hline 12 & Meskipun telah gagal dan mengalami kesalahan saya tidak akan mengutuk diri saya sendiri \\
\hline 13 & $\begin{array}{l}\text { Ketika saya menyalahkan diri saya sendiri atas kesalahan yang telah saya perbuat, saya akan segera } \\
\text { berhenti melakukannya }\end{array}$ \\
\hline 14 & Menyalahi diri sendiri bagi saya merupakan hal yang membuang-buang waktu \\
\hline 15 & Ketika gagal dan salah saya akan mencari jalan keluar bukan menyalahkan diri saya \\
\hline $16^{*}$ & Saya tidak terlalu memikirkan pendapat orang lain yang membuat saya down \\
\hline $17 * *$ & $\begin{array}{l}\text { Meskipun merasa kesalahan saya membuat diri saya tak berarti, saya tetap melakukan aktivitas yang dapat } \\
\text { membangun diri saya }\end{array}$ \\
\hline 18 & $\begin{array}{l}\text { Setiap pengalaman, kegagalan, dan kesalahan akan saya jadikan pondasi agar saya bisa menjadi lebih kuat } \\
\text { lagi }\end{array}$ \\
\hline 19 & Saya yakin bahwa saya mampu dan bisa untuk menghadapi hari-hari saya. \\
\hline
\end{tabular}

Tahap 4, dilakukan uji coba item awal pada subjek yang memiliki karakteristik serupa dengan subjek target. Pada tahap ini, responden diminta untuk membaca dan mengerjakan skala dengan seksama. Uji coba ini bertujuan untuk memperbaiki aitem- aitem yang ambigu, sulit dipahami, atau mungkin membingungkan subjek.

Kemudian pada tahap 5, dilakukan pengujian lapangan. Tujuan tahap ini yaitu untuk menyeleksi aitem pada tahap 6 . Seleksi aitem dilakukan berdasarkan daya 
beda aitem, analisis struktur internal skala dengan analisis faktor, dan estimasi koefisien reliabilitas dengan Cronbach's alpha. Aitem yang dikategorikan baik apabila memiliki indeks daya beda minimal .3 sesuai saran Ebel dan Frisbie (1991). Tahap analisis faktor dilakukan menggunakan Principal component analysis dengan rotasi varimax. Pada tahap terakhir, aitem yang lolos seleksi aitem, disusun ulang untuk mendapatkan skala final.

\section{Hasil Penelitian dan Pembahasan}

\section{Validitas Isi}

Sejumlah 22 rater yang merupakan mahasiswa Psikologi UNY semester 6 (telah mengambil mata kuliah Psikometri dan konstruksi alat ukur) terlibat dalam pengujian validitas isi aitem. Hasilnya diketahui bahwa 19 aitem memiliki indeks Aiken's V berkisar dari .82 hingga 98 . Indeks Aiken yang didapat menujukkan bahwa seluruh aitem memenuhi kriteria yang ditetapkan Aiken, yaitu untuk rater sejumlah 22 orang dengan jumlah rating kategori 5 minimal indeks Aiken's $\mathrm{V}$ yang harus dipenuhi yaitu .68 pada $\mathrm{p}=.009$ (Aiken, 1985).

\section{Studi Preliminari}

Pada studi awal, 30 mahasiswa angkatan 2019 yang berdomisili di Yogyakarta diminta mengisi skala secara online melalui Google Form yang dibagikan melalui aplikasi Whatsapp. Daya beda aitem diestimasi melalui komputasi Item total correlation dengan koreksi terhadap efek spurious overlap untuk menghindari overestimasi sesuai saran Guilford (Azwar, 2016). Pada tahap ini, dua aitem (aitem 8 dan 16) gugur karena memiliki daya beda aitem $<.3$. Tujuh belas aitem lainnya lolos dengan daya beda berkisar dari .314 hingga .752 .
Daya Beda Aitem

Analisis daya beda aitem, struktur internal, dan reliabilitas dilakukan berdasarkan data dari pengujian lapangan. Pengujian ini melibatkan 102 responden $\quad(78.4 \%$ perempuan, $21.6 \%$ laki-laki) yang merupakan mahasiswa angkatan 2019 berusia 18 hingga 21 tahun (mean=18.774, $\mathrm{SD}=.673)$. Responden mengisi skala melalui Google form yang disebarkan melalui aplikasi Whatsapp. Berdasarkan pengisian responden tersebut, 17 aitem pemaafan diri dikalkulasi daya beda. Hasil analisis daya beda menunjukkan ada dua aitem yaitu aitem 2 dan 17 memiliki daya beda $<.3$ sehingga perlu dieliminasi. Lima belas aitem yang lolos memiliki daya beda berkisar dari .354 hingga .626.

Struktur Internal Aitem dengan Analisis Faktor Lima belas aitem dengan daya beda $>.3$ dianalisis dengan analisis faktor. Peneliti menggunakan Principal Component Analysis (PCA) dengan rotasi varimax dan penetapan fixed factor sebanyak dua. The KaiserMeyer-Olkin digunakan untuk mengetahui ketercukupan jumlah sampel untuk analisis. Nilai $\mathrm{KMO}=.842$ menunjukkan bahwa sampel dalam analisis memenuhi batas kriteria Kaiser (1974; Field, 2005) yang menetapkan batas penerimaan KMO yaitu .5. Nilai KMO .842 masuk kategori baik (meritorious). Barlett's Test of sphrecity $\chi^{2}(105)=558.289, \quad \mathrm{p}<.01 \quad$ mengindikasikan bahwa korelasi antar item memenuhi untuk Pricipal Component Analysis (PCA).

\section{Tabel 3.}

Rotated component matrix dari 15 item skala pemaafan diri

\begin{tabular}{llll}
\hline Dimensi & Item & I & II \\
\hline Mengakui & 1 & .487 & \\
tanggung & $\mathbf{3}$ & .766 & \\
jawab & 4 & .760 &
\end{tabular}




\begin{tabular}{llll} 
& $\mathbf{5}$ & $\mathbf{. 5 2 9}$ & .325 \\
& $\mathbf{6}$ &. $\mathbf{8 0 1}$ & \\
& $\mathbf{7}$ & .720 & \\
& $9 *$ & .356 & .397 \\
& $10^{*}$ & .493 & .531 \\
& $\mathbf{1 1}$ & .411 & .405 \\
Memperbarui & $\mathbf{1 2}$ & .345 & $\mathbf{. 6 1 5}$ \\
harga diri & $\mathbf{1 3}$ & &. $\mathbf{7 2 5}$ \\
& $\mathbf{1 4}$ & &. $\mathbf{7 3 3}$ \\
& $\mathbf{1 5}$ & &. $\mathbf{7 0 4}$ \\
& $\mathbf{1 8}$ & .353 & $\mathbf{. 5 1 3}$ \\
& $\mathbf{1 9}$ & .426 & $\mathbf{. 5 6 9}$ \\
\hline
\end{tabular}

Tabel 4

Informasi 13 aitem akhir skala pemaafan diri *aitem cross loading

Analisis awal dilakukan untuk mendapatkan eigenvalue dari setiap komponen di data. Dua komponen memiliki eigenvalue di atas kriteria minimal 1 yang ditetapkan Kaiser (Field, 2005; Kuczaj \& Kristiansen, 2013). Dua dimensi tersebut mampu menjelaskan $47.94 \%$ dari varian.

\begin{tabular}{lllll}
\hline Dimensi & Aitem lama & Aitem final & Daya Beda & Reliabilitas \\
\hline Mengakui tanggung jawab & $1,3,4,5,6,7,11$ & $1-7$ & $.337-.676$ & .798 \\
Memperbarui harga diri & $12,13,14,15,18,19$ & $8-13$ & $.436-.609$ & .779
\end{tabular}

Berdasar Tabel 3, terdapat dua aitem (9) dan 10) yang mengalami cross loading atau mengelompok tidak sesuai faktornya. Aitem 9 dan 10 yang harusnya memiliki factor loading tinggi di komponen I, memiliki factor loading lebih tinggi di komponen II. Peneliti kemudian melakukan analisis faktor kembali pada 13 aitem tanpa menyertakan aitem 9 dan 10 yang mengalami cross loading. Hal ini karena dua aitem cross loading mencerminkan bahwa kedua aitem tersebut tidak mampu mengukur dimensi yang shearusnya diukur sehingga perlu dieliminasi.

Hasil analisis faktor pada 13 aitem didapat nilai $\mathrm{KMO}=.833$ yang menunjukkan ketercukupan sampel. Kemudian Barlett's Test of sphrecity $\chi^{2}(78)=447.594, p<.01$ mengindikasikan bahwa korelasi antar item memenuhi untuk Pricipal Component Analysis (PCA). Dua dimensi hasil ekstraksi dan rotasi menjelaskan sebesar 49.891\% varian. Aitem 1,3,4,5,6,7,11 mengelompok di komponen 1 yang merepresentasikan dimensi "mengakui tanggung jawab”. Aitem 12,13,14,15,18,19 mengelompok di komponen II yang merepresentasikan "memperbarui harga diri."

\section{Reliabilitas Skala}

Estimasi reliabilitas dengan Cronbach's alpha dilakukan pada aitem yang mengelompok sesuai komponennya. Reliabilitas Cronbach's alpha dimensi 1 "mengakui tanggung jawab" ditemukan sebesar .798 dan pada dimensi 2 "memperbarui harga diri" sebesar .779. Hasil reliabilitas dua dimensi pemaafan diri termasuk dalam kategori baik. Hal ini sesuai kriteria yang ditetapkan Nunnally dan Bernstein (1994) bahwa reliabilitas Cronbach's alpha di atas .7 masih dalam kategori baik.

\section{Diskusi}

Skala pemaafan diri yang dihasilkan dalam penelitian ini terdiri dari 13 aitem. Sedikitnya jumlah aitem dalam skala ini, di satu sisi memiliki keunggulan yaitu skala ringkas dan dapat dikerjakan dalam waktu yang singkat. Namun di sisi lain, jumlah aitem yang hanya 13 ini mungkin yang membuat reliabilitas skala ini agak mepet di sekitar .7 sebab panjang suatu tes memang 
berpengaruh pada reliabilitas (Azwar, 2015; Furr \& Bacharach, 2014). Meskipun, dalam analisis faktor yang dilakukan hasil KMO yang didapat termasuk dalam kategori baik terkait ketercukupan sampel, untuk pengembangan lebih jauh akan lebih baik jika sampel lebih besar dilibatkan dalam

\section{Simpulan}

Berdasarkan tahapan pengembangan skala yang dilakukan peneliti, dihasilkan skala pemaafan diri yang memiliki property psikometri yang cukup baik. Hasil uji validitas isi dengan Aiken's V pada 19 aitem awal menunjukkan bahwa aitemaitem awal skala pemaafan diri secara konten dinilai mampu mencerminkan dan mengukur pemaafan diri dengan baik karena indeks Aiken's V melebihi kriteria minimum dari Aiken (1985).

Hasil analisis uji awal hingga seleksi aitem berdasarkan pengujian dengan sampel lebih besar menghasilkan 13 aitem akhir dari skala pemaafan diri sehingga ada 6 aitem yang dieliminasi. Tiga belas aitem akhir ini memiliki daya beda berkisar .337 hingga .676 yang mencerminkan bahwa ketiga belas aitem mampu membedakan individu yang memiliki skor tinggi pemaafan diri dengan individu yang memiliki skor rendah. Aitem akhir skala pemaafan diri juga memiliki struktur internal yang cukup baik berdasarkan analisis faktor dengan principal component analysis dengan penetapan fixed factor 2 sesuai teori. Dua dimensi skala pemaafan diri mampu menjelaskan sebesar 49.891\% varian. Reliabilitas pada kedua dimensi skala pemaafan diri juga tergolong baik sehingga skala pemaafan diri mampu menghasilkan skor yang konsisten. pengembangan skala ini. Kemudian terkait sampel terbatas, peneliti belum menyusun panduan untuk pengkategorian skor pemaafan diri. Hal ini kemudian dapat dijadikan pertimbangan untuk penelitian selanjutnya terkait penyusunan norma untuk interpretasi skor yang lebih stabil.

\section{Daftar Pustaka}

Agung, I. M. (2015). Pengembangan dan Validasi Pengukuran Skala Pemaafan TRIM-18. Jumal Psikologi UIN Sultan Syarif Kasim Riau, 11(Desember), 79-87.

Aiken, L. R. (1985). Three coefficients for analyzing the reliability and validity of ratings. Educational and Psychological Measurement, 45(1), 131-142. https://doi.org/10.1177/00131644854 51012

Aiken, Lewis R. (1985). Three coefficients for analyzing the reliability and validity of ratings. Educational and Psychological Measurement, 45(1), 131-142. https://doi.org/10.1177/00131644854 51012

Allen, M. J., \& Yen, W. M. (1979). Introduction to measurement theory. California: Wadsworth.

Azwar, S. (2015). Reliabilitas dan validitas [Reliability and validity]. Yogyakarta: Pustaka Pelajar.

Azwar, S. (2016). Penyusunan skala psikologi [Constructing a psychological scale]. Yogyakarta: Pustaka Pelajar.

Cohen, R. J., \& Swerdlik, M. E. (2010). Psychological testing and assessment: An introduction to test and measurement 7 th edition. SIngapore: McGraw-Hill.

Cornish, M. A., \& Wade, N. G. (2015). A therapeutic model of self-forgiveness with intervention strategies for counselors. Journal Counseling and 
Development, 93(I), 96-104.

https://doi.org/10.1002/j.1556-

6676.2015.00185.x

Ebel, R. L., \& Frisbie, D. A. (1991).

Essentials of educational measurement. In Prentice Hall International (Vol. 11). https://doi.org/10.1016/00224405(73)90057-5

Enright, R. D. (1996). Counseling within the forgiveness triad: On forgiving, receiving forgiveness, and selfforgiveness. Counseling and V alues, 40(2), 107-126.

Field, A. (2005). Discovering Statistics using SPSS third edition. In Sage (Vol. 2nd). https://doi.org/10.1016/j.landurbplan. 2008.06.008

Fincham, F. D., \& May, R. W. (2019). Selfforgiveness and well-being. Does divine forgiveness matter? Journal of Positive Psychology, 14(6), 854-859. https://doi.org/10.1080/17439760.201 9.1579361

Fisher, M. L., \& Exline, J. J. (2006). Self forgiveness versus excusing: The roles of remorse, effort, and acceptance of responsibility. Self and Identity, 5(2), 127 146.

https://doi.org/10.1080/15298860600 586123

Furr, R. M. (2011). Scale construction and psychometrics for social and personality psychology. London: SAGE Publications Ltd.

Furr, R. M., \& Bacharach, V. R. (2014). Psychometrics and introduction. Boston: SAGE Publication Inc.

Gregory, R. J. (2015). Psychological testing: History, principles, and applications (Seventh Ed). https://doi.org/10.1017/CBO9780511 813757

Hall, J. H., \& Fincham, F. D. (2005). Selfforgiveness: The stepchild of forgiveness research. 24(5), 621-637.
Kaiser, H. F. (1974). An index of factorial simplicity. Psychometrika, 39(1), 31-36. https://doi.org/10.1007/BF02291575

Kuczaj, S., \& Kristiansen, R. E. (2013). The use of a Five Factor Model in Equine Personality Research. International Journal of Comparative Psychology, 26(4), 267-280.

Nashori, F. (2011). Meningkatkan Kualitas Hidup dengan Pemaafan. Unisia, 33(75), 214-226.

https://doi.org/10.20885/unisia.vol33. iss 75.art1

Nunnally, J. C., \& Bernstein, I. H. (1994). Psychometric Theory. Psychometric Theory, Vol. 3, pp. 248-292.

Tenklova, L., \& Slezackova, A. (2016). Differences between self-forgiveness and interpersonal forgiveness in relation to mental health. Journal of the Indian Academy of Applied Psychology, 42(2), 282-290.

Thompson, L. Y., \& Snyder, C. . (2005). Heartland forgiveness scale. Department of Psychology, University of Nebraska

Toussaint, L., Barry, M., Angus, D., Bornfriend, L., \& Markman, M. (2017). Self-forgiveness is associated with reduced psychological distress in cancer patients and unmatched caregivers: Hope and self-blame as mediating mechanisms. Journal of Psychosocial Oncology, 35(5), 544-560. https://doi.org/10.1080/07347332.201 7.1309615

Wijayanti, I. (2016). Work engagement ditinjau dari job demands dan job characteristic dengan quality of work life sebagai mediator [Work. engagement viewed from job demands, job quality characteristic, and quality of work life as mediator]. Universitas Gadjah Mada.

Woodyatt, L., Worthington, E. L., Wenzel, M., \& Griffin, B. J. (Eds.). (2017). Handbook of the Psychology of SelfForgiveness. Retrieved from DOI 10.1007/978-3-319-60573-9 
Worthington, E. L. (2013). Moving forward: Six steps to forgiving yourself and breaking free from the past. Journal of Psychology and Christianity, 32(2), 171.

Yao, S., Chen, J., Yu, X., \& Sang, J. (2017). Mediator roles of interpersonal forgiveness and self-forgiveness

between self-esteem and subjective

well-being. Current Psychology, 36, 585592. https://doi.org/10.1007/s12144016-9447-x 


\section{Lampiran}

Tabel 5.

Blue-print skala pemaafan diri akhir

\begin{tabular}{cllcc}
\hline No & \multicolumn{1}{c}{ Dimensi } & \multicolumn{1}{c}{ Indikator } & No Baru & Jumlah \\
\hline 1. & $\begin{array}{l}\text { Mengakui tanggung } \\
\text { jawab }\end{array}$ & $\begin{array}{l}\text { Bertanggung jawab tanpa melepaskan } \\
\text { kesalahan yang telah diperbuat } \\
\text { Berusaha memperbaiki kesalahan } \\
\text { yang dibuat } \\
\text { Mengakui kegagalan yang dialami }\end{array}$ & 1,2 & 2 \\
& & $3,4,5,6$ & 4 \\
\hline 2. & $\begin{array}{l}\text { Memperbaharui harga } \\
\text { diri }\end{array}$ & $\begin{array}{l}\text { Berhenti menyalahkan diri sendiri } \\
\text { Berusaha memulihkan harga diri }\end{array}$ & $8,9,10,11$ & 4 \\
\hline
\end{tabular}

\section{Skala Pemaafan Diri (13 aitem final)}

Beriah tanda $(\mathrm{X})$ pada masing-masing peryataan yang tertera, isikan sesuai dengan kondisi anda. STS untuk Sangat Tidak Sesuai, TS untuk Tidak Sesuai, S untuk Sesuai, dan SS untuk Sangat Sesuai. Isikan dengan teliti dan pastikan tidak ada pernyataan yang terlewat.

\begin{tabular}{|c|c|c|c|c|c|}
\hline No. & Pernyataan & STS & TS & $\mathbf{S}$ & SS \\
\hline 1. & $\begin{array}{l}\text { Saya melakukan tugas dan kewajiban saya sebagaimana mestinya } \\
\text { meskipun saya telah melakukan kesalahan }\end{array}$ & & & & \\
\hline 2. & Saya bertanggung jawab atas kesalahan yang saya lakukan & & & & \\
\hline 3. & $\begin{array}{l}\text { Apabila melakukan kesalahan saya berusaha mencari jalan } \\
\text { keluarnya }\end{array}$ & & & & \\
\hline 4. & Saya mampu untuk memperbaiki kesalahan yang saya buat & & & & \\
\hline 5. & $\begin{array}{l}\text { Ketika saya melakukan kesalahan saya berusaha untuk } \\
\text { memperbaikinya }\end{array}$ & & & & \\
\hline 6. & $\begin{array}{l}\text { Meskipun saya merasa memperbaiki kesalahan merupakan hal } \\
\text { yang sulit saya tidak menyerah begitu saja }\end{array}$ & & & & \\
\hline 7. & $\begin{array}{l}\text { Kegagalan yang saya alami tidak akan mengganggu saya untuk } \\
\text { tetap berproses }\end{array}$ & & & & \\
\hline 8. & $\begin{array}{l}\text { Meskipun telah gagal dan mengalami kesalahan saya tidak akan } \\
\text { mengutuk diri saya sendiri }\end{array}$ & & & & \\
\hline 9. & $\begin{array}{l}\text { Ketika saya menyalahkan diri saya sendiri atas kesalahan yang } \\
\text { telah saya perbuat, saya akan segera berhenti melakukannya }\end{array}$ & & & & \\
\hline 10. & $\begin{array}{l}\text { Menyalahi diri sendiri bagi saya merupakan hal yang membuang- } \\
\text { buang waktu }\end{array}$ & & & & \\
\hline 11. & $\begin{array}{l}\text { Ketika gagal dan salah saya akan mencari jalan keluar bukan } \\
\text { menyalahkan diri saya }\end{array}$ & & & & \\
\hline 12. & $\begin{array}{l}\text { Setiap pengalaman, kegagalan, dan kesalahan akan saya jadikan } \\
\text { pondasi agar saya bisa menjadi lebih kuat lagi }\end{array}$ & & & & \\
\hline 13. & $\begin{array}{l}\text { Saya yakin bahwa saya mampu dan bisa untuk menghadapi hari- } \\
\text { hari saya. }\end{array}$ & & & & \\
\hline
\end{tabular}

